The Third Pole: Journal of Geography

Vol. 20 - 21: 9-16, 2021

DOI: https://doi.org/10.3126/ttp.v21i01.41614

Department of Geography Education,

Central Department of Education, T.U., Kathmandu, Nepal

\title{
TEACHERS' PERCEPTIONS TOWARD USING GEOGRAPHY TEXTBOOKS: A STUDY IN SECONDARY SCHOOLS IN NEPAL
}

\begin{abstract}
Keshav Raj Dhakal ${ }^{1}$
Abstract

This paper is an attempt to examine the teacher's perception on use of geography textbooks at the secondary school level in the Kathmandu district of Bagmati Province, Nepal. Eight geography teachers who teach geography in community secondary schools were selected purposively. The semi-structured interview and class observation method were used to obtain on the teacher's perceptions regarding the usages of secondary level geography textbooks. The classroom observation was used to see how teachers used geography textbooks in the classrooms by observation protocol. The interviews were recorded on audio recorder and transcribed it. The data obtained from interviews provided more profound answers and crossed check accuracy of the observational data. After collecting necessary data, analysis of the data acquired from semi-structured interviews and classroom observations were made through the interpretative method by combining different sources of data. The results reveal that geography teachers who had pro-textbook views believed that their teaching could be conducted effectively using the textbooks. By contrast, teachers who had anti-textbook views believe that geography textbook was inadequate and ineffective. Secondary level geography textbooks contain both potential and limitations. The teacher should supplement geography textbooks with other authentic teaching materials to give learners more learning.
\end{abstract}

Keywords: Perception, textbook, qualitative research, pro-textbook views, antitextbook views

\section{Introduction}

The education system in Nepal has prescribed two levels of school education system i.e., basic school education (grades 1 to 8 ) and secondary school education (grades 9

1 Dhakal is a Associate Professor, Central Department of Education, Research Scholar in Geography 
to 12). The curriculum development center is the apex body that develops the school curricula and other curricular materials, including textbooks in Nepal. Different experts in the field using equipped teaching devices write textbooks. Textbooks are produced through consultations that are more comprehensive and are based on extensive research. Textbooks reflect the aims and objectives of the concerned curriculum. The National Curriculum Framework (2076) has emphasized on the development of student-centered textbooks to systematize school-level education. The geographical concept is taught as an integrated course at the basic and secondary levels (in grades 1-11 as a part of social studies courses). In secondary school, students take geography from 9 to 12 grades as an optional subject in Nepal. The quality of the education system depends on the interaction between teachers and students with textbooks in the classroom. Therefore, the use of textbooks in the teaching-learning process is very significant.

Textbooks carry a wide range of new and exciting facts and open the door to a world of a unique experience. The textbook is a book used as a standard source of information for the formal study of a subject and an instrument for teaching and learning (Graves, 2000). According to Esteves (2019), textbooks play a vital role in preparing of teaching activities, i.e., they are a significant source of information and activities to be implemented in the schools classroom. However, there are great varieties of tools and materials used in school education, and textbooks maintain their leading role. Textbooks are the most common instructional materials used in the geography classrooms. Textbooks support their importance, and teachers are carrying out many classroom activities through textbooks (Artivinil, 2009). It is both content and techniques. The textbook is also called the teacher in print. In the Nepalese educational system, textbooks are considered as the main components of the curriculum.

Textbooks play an important role in preparing teaching activities, i.e., they are a significant source of information and activities to be implemented in the school classroom. The textbook is a book containing facts about a particular subject that is used by people studying that subject and is produced according to the demand of educational institutions (Dhakal, 2019). The textbook is an important resource in the teaching and learning process in school education for both teachers and students. Textbooks accomplish different functions for students and teachers. Textbooks carry a wide range of new facts, which open the door to a world of a completely new experience. Teachers should play an important role in students' creative potential by the proper use of textbooks. Textbooks help teachers to become more inspirational and motivational. For teachers, textbooks are viewed as pedagogical tools due to informative, dissemination, formative, and supportive dimensions and provide structure and contents to use in the classroom. 
Textbooks are directed to students, and usually, the authors regard the student as the primary reader (Kang \& Kilpatrick, 1992). With the aid of the textbooks as a resource, the students recapitulate, assimilate, and internalize what learned in their classroom. The textbook can provoke questions and induce students to supplement the information it contains. A good textbook encourages the student to think and stimulates critical reflection. From students' perspective, textbooks should be attractive, reflect students' need and interests, and give them chapter review problems and sample tests to answer. Widdowson \& Lambert (2005) stated that textbooks have a crucial place in teaching learning.

Lambert (1999) identified the different functions of textbooks. They are used in the classroom as management tools by the teacher to control students' behavior. Textbooks are used to structure lessons as provide curricular topics following the curricular sequence. The research also recognizes the central role of textbooks as curriculum mediators and textbooks are also viewed as having a support role to teachers' activities the primary source of knowledge.

Graves (2000) identified the usefulness of textbooks in their relationship with pedagogical practice. He mentions several features of textbook relevance in the educational process. They are organized into the content to be learned. However, textbook authors have selected topics and organized them in sequential order. It facilitates the organization of classroom activities to be undertaken, they provide more information used by the teacher (and worked with students) in terms of activities, texts, images, etc., textbooks enable learning assessment moments (most textbooks include assessment tools), they consist of supporting materials to be used in classes (teacher's guidelines, worksheets with additional information and activities). They play an essential role in assuring consistency of the curriculum in different levels of schooling (textbooks follow the same sequence defined by the subject syllabus).

Research demonstrates that textbooks are an essential resource to teachers and students in school level education. Thus, it was essential to assess how geography teachers use textbooks in their classes. Teachers' perceptions are more important to understand how they adapt to curricular reforms, and overcome the shortcomings of textbooks preparation. In this regard, the present study intends to examine the perception of geography teachers towards using geography textbooks in their classroom.

\section{Methods and Materials}

A qualitative research has been used in this study. Qualitative research involves emerging questions and procedures, data typically collected in the participant's setting, 
data analysis inductively building from particulars to general themes, and the researcher making interpretations of the meaning of the data (Creswell, 2008). This research is a descriptive study to collect geography teacher's perceptions of the use of textbooks in their classroom practice in secondary schools. Eight secondary schools were selected for the study based on purposive sampling out of sixteen community secondary schools offering geography as an optional subject in Kathmandu district, Bagmati Province. Eight teachers who teach geography in sampled community secondary schools were selected. The researcher visited the sampled schools to gather the necessary data.

Semi-structured interviews, and classroom observations were used to obtain data on the teacher's perceptions regarding the usages of secondary level geography textbooks. According to Bernard (1988), semi-structured interviewing is best used when you won't get more than one chance to interview someone and when you will be sending several interviewers out into the field to collect data. All the interviews were voice-recorded with the respondents' permission and later transcribed. The classroom observation was applied to see how geography teachers used geography textbooks in the classrooms. Observation is a direct way of gathering information to observe events as they occur (Wolf $\&$ Pant, 2005). The researchers also used classroom observation protocol to observing classrooms situation. The data collected from semi-structured interviews provided more profound answers and check accuracy of the observational data. The secondary data were acquired from reviewing the published, and electronic materials, and documents of various organizations. After collecting data, analysis of the data obtained from semistructured interviews, and classroom observations were made through the interpretative method by combining and merging different sources of data.

\section{Results and Discussions}

Teachers' Perceptions of the use of Textbooks: Eight geography teachers teaching geography in eight different community secondary schools located in the Kathmandu district responded to the survey. Out of the eight secondary level teachers teaching geography is the research population, all teachers are male. All teachers had at least a bachelor's degree in geography from University. In terms of year of service, $50 \%$ of the teacher had a teaching experience over ten years, $25 \%$ had teaching experience between 5-10 years, and 25\% had a teaching experience less than five years in study area. All teachers participated in the teacher training program after they were appointed as geography teachers.

Teachers' perceptions of the use of textbooks can be approached in two ways. The detailed insight into teachers' perceptions towards the use of geography textbooks 
and problems about using the textbooks were elicited from the data obtained from the semi-structured interviews and classroom observation. What one teacher considers an advantage in a textbook, another teacher may consider a disadvantage (Graves, 2000).75\% of respondents reported textbooks are used either every lesson in class. This clearly represents a dominant presence of textbooks in classrooms. Those teachers require their students to bring their textbook every lesson just in case it is needed. Only $25 \%$ of respondents have anti-textbook views on the daily use of only textbooks in the geography classrooms. The anti-textbook views refer to the perceptions of teachers who believe that using a textbook is not a good job in teaching and learning.

The pro-textbook views: Textbooks give a significant contribution to the teachinglearning process both to the teachers and to learners. The pro textbook views refer to the perceptions of the teachers who believed that geography textbooks were necessary teaching materials and using geography textbooks helped them to teach geography effectively. The pro-textbook teachers used textbooks in every phase of teaching and learning activities. The pro-textbook teachers followed textbooks' descriptions and gave explanations according to what textbooks provided. The teachers who had the pro textbook views considered textbooks as instructional frameworks because textbooks assisted them when preparing lessons. Geography textbooks also served as sources of direction and ideas for teachers about how lectures can be delivered. They felt confident to use textbooks as their source of teaching. Some teachers explained that they rarely used other teaching materials to supplement their classroom teaching. They said that their teaching would be challenging without the use of textbooks, and they also preferred using textbooks to additional teaching materials. They also stated that they use textbooks outside the classroom as aids in planning lessons. Those who chose textbooks used them in every phase of teaching and learning. It was revealed from the class observation that the pro textbook teacher used most exercises provided in the textbook. One of the teachers mentioned that:

The geography textbook is the best guideline for me in teaching in the class room. Textbooks gave me a framework and guidelines of how lessons would be conducted. If we do not use geography textbooks, we will not have any framework and procedures to follow the curriculum.

The pro textbook teachers believed that geography textbook considerably reduced their teaching preparation time because they provided detailed activities and exercises for teachers. They further stated that textbooks were influential teaching materials that saved both time and money. O' Neill (1982), Sheldon (1988) \& Ur (1988) mention that textbooks are efficient tools in terms of time and money. Textbooks helped to save 
teachers' time in preparation because textbooks provided detailed activities and exercises for them. They indicated that using textbooks was the best way, which reduced teachers' planning. They also stated that they use textbooks outside the classroom as materials in planning lessons. One of the teachers mentioned that:

The textbook is an effective teaching material, which helps reduce my workload. Nowadays, teachers have more responsibilities in school and must handle different tasks. We do not have a huge amount of time in material preparation and making different plans, so textbook helps a lot for me. Textbooks are the most popular teaching materials used in the classroom.

The teachers who preferred the textbook pointed out that they explained based on the provided by textbooks. Classroom observation also followed the textbooks section description with a few details. They deemed the textbook reliable and necessary. The textbook helps teachers to teach geography effectively. One of the teachers stated that:

The geography textbook is essential for teaching and learning in Nepalese contexts. Teachers do not have any standards to measure learners' achievement without the use of textbook. Teachers cannot measure the learner's achievement fairly if teachers use different teaching materials. The textbook is source of assessment items. The textbook provides adequate guidance for the teacher and not too heavy a preparation load.

The pro textbook teachers believed that geography textbooks an essential teaching and learning materials. They further stated that geography textbook is time-saving andmoney saving materials for teachers. Geography textbooks are more durable and can be used more extended time than other supplementary materials like handouts and worksheets. It provides consistency within a program across a given level because all teachers use the same textbook in their classroom. If textbooks follow a sequence, as within a series, it provides consistency between classes.

The anti-textbook views: The massive use of textbooks is considered an educational failure (Swales, 1980). According to anti-textbook views using textbooks can potentially obstruct teachers from success in teaching. The anti-textbook statements refer to the perceptions of teachers who believed that using only the textbook was not a good job while teaching in the classroom. The teacher who had anti-textbook views thought that the educational system in Nepal was an exam-oriented system and the geography textbooks failed to provide learners what they needed in this respect. Teachers revealed that textbooks were inadequate to suit learners' needs. Ur (1998) asserts that textbooks are insufficient in terms of supplying every learner's needs. The teacher expressed that textbooks contained little content explanation, insufficient exercise, and examples. It 
was also observed from the observation of the geography classroom that teacher used other supplementary materials in the geography classroom. One of the teachers stated that:

I feel mainly two types of difficulties that are the level of difficulty of textbooks and the limited teaching materials. Textbooks are not updated in terms of changing society. The teacher has opinions about textbooks determine, and control the methods, processes and procedures of teaching and learning.

Additionally, teachers indicated that the content of the textbooks were less relevant to their learners' needs. As observed from their lessons, anti-textbook teachers employed their styles of presentation and rarely followed textbooks. Moreover, teachers said that content provided in the geography textbooks did not match the majority of the learners' needs and interests. A single textbook does not meet the diverse needs of the learners in classroom. Teachers who had anti-textbook views mentioned that some topics and contents were not relevant beyond learners' ability. They finally concluded that they preferred using teacher-made materials and supplementary books. One of the teachers stated that:

Some topics are (map work, fieldwork) insufficient in textbooks to provide and promote the autonomous work of students. Only the geography textbook published by the curriculum development center could not serve all learners' need. Textbooks also fail to depict real-life situations. We made different efforts to solve the problems or difficulties in using textbooks.

The anti-textbook views teachers believed that geography textbooks have two main difficulties in using textbooks by teachers. The difficulty level of the textbooks, and limited aids for teaching are the significant difficulties in using geography textbooks in classrooms. They further stated that maps and diagrams in geography textbooks are small. Examples based on local geography should emphasize in the textbook.

\section{Conclusion}

This study was carried out to map the geography teachers' perceptions about the use of geography textbooks. Most of the teachers considered geography textbooks as being essential teaching material in their teaching-learning process. Some teachers who were anti-textbook views believed that their limitation prevented them from being helpful to support. The pro-textbook teacher stated that the geography textbook served as instructional frameworks, guidelines, and sources of direction for them. The protextbook teachers believe that textbooks are reliable sources, and save both money, and 
time, whereas those who had anti-textbook views, the geography textbook failed to suit learners' need. They pointed out that topics and content in the textbook were not relevant in the present changing society. They stated that the significant problems of geography textbooks were inadequate and irrelevant to the learners. Secondary level geography textbooks contain both potential and limitations. Concerned authorities need to modify the textbook where necessary. Teachers should supplement geography textbooks with other authentic teaching materials to give learners more learning.

\section{References}

Artvinli, E. (2009). The level of the access to geographic skills in the 9 year geography textbook according to geography curriculum. Erzincan University Journal of Education Faculty, 11(2), pp. 51-66.

Bernard, H. R. (1988). Research methods in cultural anthropology. Newbury Park, CA: Sage Publications.

Cresswell, J. W. (2009). Research design; qualitative, quantitative, and mixed methods approaches. New Delhi: Sage Publications.

Dhakal, K.R. (2019). Teaching Geography in Secondary Schools: Teachers perceptions and experiences. The Geographic Base, (6), pp.32-41.

Esteves, M.H., (2019). Geography teachers' views on textbook use in Portugal: a small-scale study in challenging times, European Journal of Geography, 10 (1), pp. 85-98.

Graves, K. (2000). Designing Language Course, a guide for teachers. Boston: Heinle Cengage Learning.

Kang, W., \& Kilpatrick, J. (1992). Didactic transposition in mathematics textbooks. For the Learning of Mathematics, pp. 12:2-7.

Lambert, D. (1999). Exploring the use of textbooks in Key Stage 3 geography classrooms: a small-scale study. The Curriculum Journal, 10(1), pp. 85-105.

O'Neill, R. (1982). Why use textbooks? ELT Journal, 36(2), pp.104-111.

Sheldon, L.E. (1988). Evaluating ELT textbooks and materials. ELT Journal, 42(4): 237-246.

Swales, J. (1980). The textbook problem. The ESP Journal, 1(1), pp. 11-23.

Ur, P. (1998). A course in language teaching: Practice and theory. Cambridge: Cambridge University Press.

Widdoson, J. \& Lambert, D. (2015). Using Geography Textbooks. GA New Secondary Teachers Handbook.pdf file retrieved on Sep.1, 2020.

Wolf, K. W. \& Pant, P.R. (2003). A handbook for social science research and thesis writing. Kathmandu: Buddha Academic Publishers and Distributors Pvt. Ltd. 